\title{
How Does Paternalistic Leadership Affect Employees' Work Engagement? The Mediating Roles of Workaholism and Trust-in-Leader
}

\author{
Ömer Erdem Koçak \\ Burcu Aydın Küçük
}

\begin{abstract}
In this study, we contend that paternalist leadership can be an effective way of managing people and can pave the way for employee motivation and well-being, despite several previous studies linking it to adverse outcomes. In addition, we propose two possible underlying mechanisms (i.e., workaholism, trust in leadership) linking a leader's paternalistic style to employee work engagement. By doing so, we aim to understand whether paternalist leaders positively influence their subordinates through a social connection path (trust in leader) or task-focusing path (workaholism). We conducted a field survey and collected cross-sectional data using online surveys from 413 participants working in various industries in Istanbul to test the hypotheses. The results indicate a positive relationship to exist between paternalistic leadership and employee work engagement. Therefore, we put forth that the paternalistic leadership style can be beneficial through the task-focusing and social connection paths, contrary to the beliefs commonly shared in Western countries.
\end{abstract}

Keywords: Paternalistic leader, work engagement, trust in leader, workaholism.

Öz: Bu çalışmada, babacan liderliğin insanları yönetmenin etkili bir yolu olabileceği ve daha önceki birkaç çalışmada olumsuz sonuçlarla ilişkilendirilmesine rağmen, çalışan motivasyonu ve esenliğine zemin hazırlayabileceği iddia edilmiştir. Ayrıca, liderin babacan tarzını çalışanın tutkun çalışmasıyla ilişkilendirmek için işkoliklik ve lidere güven ile temsil edilen iki temel muhtemel mekanizma önerilmiştir. Böylece, babacan liderlerin astlarını sosyal bağ yolu (lidere güven) veya göreve odaklanma yoluyla (işkolik) olumlu yönde etkileyip etkilemediğinin anlaşılması amaçlanmıştır. Hipotezleri test etmek için bir saha araştırması yapılmış ve İstanbul'da çeşitli sektörlerde çalışan 413 katılımcıdan çevrimiçi anketler aracılığıyla kesitsel veriler toplanmıştır. Analizler, babacan lider ile çalışmaya tutkunluk arasında pozitif bir ilişki olduğunu. Dahası, önerilen muhtemel mekanizmaların babacan liderlik ile çalışmaya tutkunluk arasındaki ilişkiye aracılık ettiğini görülmüştür. Bu nedenle babacan liderlik tarzının, batı ülkelerinde yaygın olarak paylaşılan inançların aksine, göreve odaklanma ve sosyal bağlantı yoluyla faydalı olabileceğini ortaya koyulmuştur.

Anahtar Kelimeler: Babacan lider, çalışmaya tutkunluk, lidere güven, işkoliklik. 


\section{Introduction}

Paternalistic leadership has gained popularity in the last two decades and is posited as an influential culture, mostly in non-Western cultures (Pellegrini \& Scandura, 2008). Some studies have also shown the effectiveness of paternalistic leadership in the context of Turkish society (e.g., Öge, Çetin, \& Top, 2018). Notably, the former literature has underlined paternalistic leadership to have roots in society and both national and organizational culture to be essential processes in the emerging form of paternalistic leadership (PL; Aycan et al., 2013). Thus, PL can result in several positive outcomes at the individual and organizational levels depending on the cultural context in which PL is enacted (Hiller et al., 2018).

In the literature on Turkish management, PL has been linked to some positive consequences, with some studies examining its successfulness in the context of Turkish culture (see Aycan et al., 2013). Although PL is known to be useful, little empirical evidence exists for this reasoning. For instance, meaningful work (Çetin et al., 2017) and collective gratitude (Bekmezci \& Yıldız, 2019) have been the only concepts employed as the underlying mechanisms to explain why and how paternalistic leadership is able to contribute to employee well-being and motivation. In order to fill this gap, we investigate two intervening processes between PL and work engagement in this study. Our study aims to address the question of what relationship-oriented and task-oriented behaviors make paternalistic leadership an effective strategy in the Turkish business context. Through this, we will be able to explain what leaders should do when utilizing a paternalistic strategy and what makes PL an attractive strategy in the eyes of their followers. Considering PL's two distinct facets (caring and authoritative), we posit that paternalistic leaders nudge their employees toward engaging in work by providing good relationships (i.e., supervisor support) while demanding extra effort (i.e., workaholism). By using self-determination theory in this study, we examine whether working with paternalistic leaders are able to fulfill employees' needs (i.e., needs of relatedness and competence) and make them engaged employees.

Firstly, we define and state which conceptualization this study will use for paternalistic leadership. Secondly, we describe work engagement and state how paternalistic leadership relates to work engagement. Thirdly, we put forth the two mediating mechanisms of workaholism and trust-in-leader to explain how paternalistic leadership leads to employee work engagement. Then by giving the methodological details, we present and discuss the study's findings and contribution to the literature, as well as its shortcomings and suggestions for future research. 


\section{Theoretical Framework}

\section{Paternalistic Leadership}

Bing (2004) asserted leaders to essentially be a mutated copy of the original authority figure when explaining the phenomenon of leadership. The person who stands out in the community and impacts others is identified as a father figure. Moccoby (2004) drew attention to the strength of paternalistic leadership, claiming the most successful leaders to have similarly demonstrated fathers' decisive role over the audience to whom they are appealing. In parallel with this, paternalistic leadership has been defined as a leadership style combining strong discipline and authority with paternal philanthropy (Farh \& Cheng, 2000, p. 86; Pellegrini \& Scandura, 2008; p. 571). Aycan (2006) also conceptualized paternalistic leaders as those who take care of their subordinates' work and non-work life, who protect their subordinates, and who expect subordinates to obey and show respect to them. A comparative study of 10 countries conducted by Aycan et al. (2000) revealed paternalistic characteristics to be more likely observed in Eastern countries such as Pakistan, China, and Turkey. Paternalism is a common cultural characteristic in Turkish culture, where the levels of affectivity and particularism have promoted the acceptance of paternalism as an appropriate leadership style (Aycan, 2006; Wasti et al., 2007). Thus, paternalistic leadership is most effective in societies characterized by high collectivism and power distance (Aycan, 2008).

The authoritarian side of PL corresponds well with the aspects of the high power distance and collectivism in Turkish culture. Cultures with high power distance favor authoritative father-figure managers and can tolerate power inequalities, whereas the collectivist side of the culture supports leaders who give importance to harmony and togetherness (Hofstede, 1980). Hofstede (2001, p. 107) used the term "a good father" for defining leaders with high power distance; this is consistent with conceptualizations of PL. Feminine aspects of the culture emphasize leadership qualities such as nurturing, protective, and indirect communication (Hofstede, 1980, 2001). A culture with high uncertainty avoidance would shape their perception of a useful leader as one who does not take too many risks, obeys the conservative norms, and behaves habitually. PL's dimensions of benevolence and moral leadership also parallel these aspects. These features of Turkish culture allow this leadership style to be productive. Thus, paternalistic leadership yields positive individual and organizational outcomes.

While previous studies have shown paternalistic leadership to pave the way for adverse outcomes such as leader bullying (Soylu, 2011) or higher turnover (Liao, 
Widowati, Hu, \& Tasman, 2017), they have also shown PL to be able to lead to positive employee behaviors such as creativeness (Kurt \& Yahyagil, 2015) and organizational citizenship behaviors (Mete \& Serin, 2015) as well as positive attitudes such as job satisfaction (Nal \& Tarım, 2019) and organizational commitment (Erben \& Güneşer, 2008).

\section{Work Engagement}

Work engagement is defined as "a positive affective-motivational fulfilling state characterized by vigor, dedication, and absorption" (Schaufeli, Salanova, GonzálezRomá, \& Bakker, 2002 p. 74). Vigor refers to having the energy available to exert the effort demanded by one's job. Dedication reflects the extent to which one shows strong involvement at the same time as enthusiasm and significance. The dimension of absorption is a pleasant state of total immersion in one's work characterized by time passing quickly and being unable to detach oneself from the job (Bakker \& Demerouti, 2002). Work engagement positively relates to positive outcomes at both organizational and individual levels. Xanthoupoulou et al.'s (2009) study found engaged workers to positively impact their organization's financial performance. Ample evidence is found at the individual level that work engagement relates to inrole performance (Christian et al., 2011), extra-role performance (Xanthoupoulou et al., 2008), and creative/innovative behaviors (Gawke et al., 2017).

Leaders are an essential part of the immediate social network at the workplace on whom followers rely when making decisions in their job environment (Salancik \& Pfeffer, 1978). This may explain the reason why leaders are known to be good when they basically inspire and personally understand workers' needs and why these employees are energized to accomplish collective goals (Breevart et al., 2014). Hence, having a good leader can enhance employee capability and motivation because good leaders usually provide their employees with resources, facilitate their task accomplishments, or optimize employees' job environment according to their needs (Smircich \& Morgan, 1982). Accordingly, employees with ample resources and a good leader are more likely to be energetic, dedicate themselves to their job, and be immersed in their work (Bakker \& Demerouti, 2014). In line with these ideas, previous studies have shown leadership style to be able to significantly explain the variance in work engagement. For instance, Tims et al. (2011) found transformational leadership to be beneficial for work engagement as it reinforces followers' resources for self-efficacy and optimism. Moreover, authentic leadership (Giallonardo, Wong, \& Iwasiw, 2010), 
servant leadership (De Clercq, Bouckenooghe, Raja, \& Matsyborska, 2014), inclusive leadership (Choi, Tran, \& Park, 2015), and ethical leadership (Cheng, Chang, Kuo \& Cheung, 2014) have also been found to contribute to employee work engagement.

Paternalistic leaders in particular can be a resource to employees or provide them with resources. They are known to be benevolent but harsh, which implies that leaders tend to support their followers, meet their needs, and challenge them to improve (Aycan, 2006). Notably, both being supported and being offered growth opportunities can enhance employee work engagement (Demerouti et al., 2001). Several studies in the context of Eastern cultures have found paternalistic leadership to foster employee work engagement, work involvement, and dedication (Ersoy, Born, Derous, \& van der Molen, 2012; Shu, 2015; Korkmaz, Gökdeniz, \& Zorlu, 2018). Öge et al. (2018) found a direct relationship between paternalistic leadership and work engagement in a sample of air traffic controllers, suggesting paternalistic leadership to be appraised as a job resource and employees to devote more energy, involvement, and focus on their work in exchange for this resource. Cenkci and Özçelik (2015) also found a significant effect, but only through PL's dimension of benevolence. Overall, because paternalistic leaders are known to care for, protect, and guide their subordinates in both their work and non-work lives (Aycan, 2006), they are seen to be supportive and to deserve loyalty. We expect paternalistic leaders to be able to increase their employees' work engagement. As a result, we propose the Hypothesis 1 as:

$\mathrm{H}_{1}$ : Paternalistic leadership has a positive effect on work engagement.

\section{Trust-in-leader as a mediator}

Trust is an essential determining factor for organizations with regard to possible antecedents and outcomes (Mayer, Davis, \& Schoorman, 1995). Based on the literature review, the most used definition of trust is "willingness to increase the resources invested in another party, based on positive expectations resulting from past positive mutual interactions" (Rousseau et al., 1998, p. 395). The trusting party assumes that the instigator will not behave opportunistically in the relationship. Indeed, a trusting party accepts certain risks, as trustors can act according to their interests (Schoorman, Mayer, \& Davis, 2007).

A growing interest in understanding and developing trust in the manager has been found as one of the dimensions of organizational trust (Podsakoff, MacKenzie, Moorman, \& Fetter, 1990; Cummings \& Bromiley, 1996; Börü, İslamoğlu, \& Birsel, 
2007; Jaiswal \& Dhar, 2017). Thus, this dimension occurs as a vital issue in the context of organizations (Burke, Sims, Lazzara, \& Salas, 2007; Six, 2007; Çıtır \& Kavi, 2010). Trust may have affect-based antecedents as trust can be shaped by past experiences and interactions (e.g., managers' attitudes and behavior. In favorable situations, employees feel an obligation to do the right thing in the relationship as a response (Diffie-Couch, 1984; Burke et al., 2007; Mo \& Shi, 2017). Employees who trust their manager tend to commit themselves to organizational goals; thus, they are motivated to show more considerable effort (e.g., in-role and extra-role performance; Dirks \& Ferrin, 2002; Brower, Lester, Korsgaard, and Dineen, 2009) and work engagement (Engelbrecht, Heine, \& Mahembe, 2017; Holland, Cooper, \& Sheehan, 2017).

Three facets of paternalistic leaders (i.e., benevolence, integrity, and ability) can enable employees to trust their manager; this helps employees be more enthusiastic about work. According to Rawat and Lyndon (2016), PL evidently impacts employees' trust levels positively. Another study showed employees' trust levels to moderate the effect of PL behaviors on employees' organizational commitment (Saher, Naz, Taleem, Naz, \& Kausar, 2013). Paternalist leaders can improve employees' trust by promoting and supporting employees both in and out of the organization; this results in interaction that emotionally satisfies both parties. As a result of high emotional interaction, employees may feel more eager to invest more relational resources to their managers or stand behind their manager's decisions. Possessing a positive interaction with the manager may create feelings of mutuality and safety and make an employee less vulnerable; this can lead to greater work engagement (Chughtai, Byrne, \& Flood, 2015).

Additionally, the theory of need fulfillment can help understand any possible relationships. Namely, as much as a manager satisfies their employees' needs, employees can experience a sense of belonging and easily attach to their organization (Patrick, Knee, Canevello, \& Lonsbary, 2007). In such a situation, one may think that trusting their leader will likely energize employees and develop higher levels of dedication and immersion at work.

In short, leaders strongly affect their employees' attitudes and emotions. Paternalistic leadership can predict long-term trust and satisfaction, happiness with work, and well-being. Because employees make sure their manager will support them in the learning process and optimize what they know, employees who trust their manager may dedicate themselves to their work by showing their best abilities. In line with this general argument, paternalistic leaders by their nature have a significant effect 
on employees' trust levels, and trust can be a potent trigger behind employee work engagement. Therefore, PL can be beneficial for building trust and helping generate employee engagement at work. Thus Hypothesis 2 is:

H2: Trust in leadership mediates the relationship between paternalistic leadership and work engagement.

\section{Workaholism as a Mediator}

Fundamentally, the concept of workaholism was first used by Oates (1971) to emphasize the similar cognitive-behavioral patterns of extreme and problematic work. A body of definitions exist for workaholism (see Clark, Smith, \& Haynes, 2020). Taris, Schaufeli, and Shimazu (2010) defined workaholism as a tendency characterized by an irresistible inner drive to work very hard as well as a combination of compulsive and excessive working. Firstly, workaholics tend to allocate an exceptional amount of time to work because they are eager to work excessively; secondly, workaholic employees persistently and frequently think about work inside and outside working hours even when they are on vacation (Libano, Llorens, Salanova, \& Schaufeli, 2010).

Meanwhile, workaholic employees can feel competent about themselves because they spend time working beyond the typical working day, which results in achievements. This concentration may contribute to the feeling of competence (Andreassen, Griffiths, Sinha, Hetland, \& Pallesen, 2016). Paternalistic leaders are known to support employees in developing themselves, thus increasing their understanding of the impact they make in the workplace (Liden et al., 2000). In addition, when employees perceive managers as empowering and supportive, they tend to invest more effort in their work. According to these statements, a leader's benevolence nurtures employees' feelings of mastery (Süer, 2017). Therefore, a manager who reinforces individuals' efforts at work have been suggested to be able to boost work engagement in the organization. PL in the workplace can be a predictor of excessive work behaviors that lead to vigor, dedication, and absorption. Reflecting on this argument, we generate Hypothesis 3 as:

H3: Workaholism mediates the relationship between paternalistic leadership and work engagement. 


\section{Method}

\section{Sample and Procedure}

We conduct a cross-sectional survey study and have recruited participants from a career-oriented social networking web page. We announced the study as a study on Turkish styles of good leadership and consequences on employee attitudes, posting advertisements and including information about the study goals and target population. As an incentive, we ensured that participants could give feedback upon request. We collected all data online using an online survey tool accessible by computers and smartphones.

In total, 876 participants clicked on the advertisement link; of these, 479 gave consent to participate in our study, of whom 424 answered at least $80 \%$ of all questions. We excluded 11 participants as the time they spent filling out the survey had been less than one minute. Thus, the data for the current study is from a sample of 413 participants from various sectors, including banking (18\%), fast-moving consumer goods (FMCG; 17\%), information technologies (11\%), health care (9\%), tourism (8\%), and others. Of the participants, $55.9 \%$ are female, and $44 \%$ have at least a university degree. The mean age is 33.4 years $(S D=10.3$; Range $=18$ to 65$)$.

\section{Instruments}

The study uses a total of four different scales to measure all the variables. The employees answered all the scales, with the items being rated on a 6-point scale ranging from 1 (totally disagree) to 6 (totally agree).

Level of work engagement has been measured using the 9-item version of the Utrecht Work Engagement Scale (UWES9; Schaufeli, Bakker, \& Salanova, 2006; see also Schaufeli et al., 2002). The scale consists of three sub-dimensions (vigor, dedication, and absorption). An example from the vigor sub-scale is "At my job, I feel strong and vigorous." An example from the dedication sub-scale is "My job inspires me," and example from the absorption sub-scale is "When I am working, I forget everything else around me." UWES9 is suggested for use as a single-factor construct (Schaufeli, Bakker, \& Salanova, 2009). Its internal consistency has been calculated as $\alpha=.84$.

Paternalistic leadership behaviors have been measured using the Paternalistic Leadership Questionnaire (PLQ) developed by Aycan, Schyns, Sun, Felfe, \& Saher (2006). PLQ is a unidimensional scale consisting of 10 items, an example item be- 
ing, "My current leader creates a family environment in the workplace." Its internal consistency is $\alpha=.91$.

Trust in leadership has been measured using a subdimension from the Trust Scale developed by Börü, İslamoğlu, and Birsel (2007). Cronbach's alpha of reliability for the scale has been found as .94. An example item from this scale is "My supervisor shares their knowledge." The internal consistency is $\alpha=.87$.

This study measures workaholic behaviors using the Dutch Work Addiction Scale (DUWAS) developed by Schaufeli, Taris, and Bakker (2006). In the original study, the scale consisted of 17 items and two-factors (i.e., working excessively and working compulsively). "I go to work while feeling ill" is an example item from working excessively, and "I usually feel that there is something inside me that pushes me to work hard." is an example item from working compulsively. DUWAS' internal consistency has been calculated as $\alpha=.84$.

\section{Strategy of Analyses}

The study has employed confirmatory factor analysis (CFA) to ensure the factorial validity of the variables (Bowen \& Guo, 2011). The study considers the thresholds suggested by $\mathrm{Hu}$ and Bentler (1999) for assessing the model fit. First, the measurement model has been tested to ensure the construct validity and reliability of the variables. After computing the variables scores by imputing the factor scores from the CFA, we used the PROCESS plug-in for SPSS developed by Hayes (2003, 2009) to test the mediation hypothesis. Ample evidence exists for the validity of the PROCESS macro (Hayes, 2017; Hayes \& Rockwood, 2017), and it provides practically the same findings compared to structural equation modeling (Hayes, Montoya, \& Rockwood, 2017). In order to ensure the presence of mediating variables, we first performed a regression analysis on the mediating variables of trust in leadership and workaholism with respect to paternalistic leadership. After this, we performed a regression analysis of work engagement in terms of both paternalistic leadership and the mediating variables. We examined the indirect effects using the 2,000 samples, 95\% confidence interval, bias-corrected bootstrapping method as suggested by Preacher and Hayes (2004). Finally, we included the demographic variables of gender, age, and education level in the analysis to check if these have any possible confounding effects. 


\section{Findings}

\section{Validity and Reliability}

The confirmatory factor analyses resulted in a good fit after excluding two items (one from work engagement, one from trust in leadership) and adding five covariances among the error terms belonging to items under the same latent construct $\left(\chi^{2}=1,046, d f=484, p<.001 ; C F I=.911, T L I=.903, R M S E A=.052, S R M R=.048\right)$. The four-factor model (paternalistic leader, work engagement, workaholism, trust in leadership) is seen to be superior to or no different from alternative models such as: (i) the five-factor model in which workaholism was divided into the separate factors of working compulsively and working excessively $\left(\Delta \chi^{2}=-54, \Delta d f=28, p<\right.$ $.01)$, (ii) the three-factor model in which work engagement and workaholism are combined $\left(\Delta \chi^{2}=-84, \Delta d f=30, p<.001\right)$, and (iii) the single-factor $\left(\Delta \chi^{2}=2,467\right.$, $\Delta d f=50, p<.001)$. Additionally, we ran Harman's single-factor test to ensure that our four-factor model is exempt from common method bias. The first factor of the exploratory factor analysis explains only $24 \%$ of the total variance, indicating a low chance of common method bias. Thus, we continued with the four-factor model as it showed clear convergent as well as discriminant validity.

\section{Table 1}

Means, Standard Deviations and Correlations Between Variables

\begin{tabular}{lcccccccc}
\hline \multicolumn{1}{c}{ Variables } & $M$ & $S D$ & 1 & 2 & 3 & 4 & 5 & 6 \\
\hline 1 Gender & 1.44 & .50 & & & & & \\
2 Education level & 3.97 & 1.21 & $0.127^{* *}$ & & & & \\
3 Age & 33.43 & 10.30 & -0.028 & -0.089 & & & \\
$\quad$ Work & 4.59 & .83 & 0.043 & -0.089 & $0.224^{* * *}$ & & \\
$4 \begin{array}{l}\text { engagement } \\
5 \text { Trust in leader }\end{array}$ & 4.65 & .87 & -0.013 & 0.096 & 0.036 & $0.215^{* * *}$ & \\
$\quad \begin{array}{l}\text { Paternalistic } \\
\text { leadership }\end{array}$ & 4.47 & 1.05 & -0.051 & $-0.109^{*}$ & 0.075 & $0.328^{* * *}$ & $0.424^{* * *}$ & \\
7 Workaholism & 4.17 & .80 & 0.075 & $-0.144^{* *}$ & $0.266^{* * *} 0.569^{* * *} 0.162^{* * *} 0.299^{* * *}$ \\
\hline$N=413$ & & & & & & & \\
$* p<.05,{ }^{* *} p<.01,{ }^{* * *} p<.001$ & & & &
\end{tabular}




\section{Hypotheses Testing}

All correlations are found significant among the focal variables (see Table 1). Paternalistic leadership is positively associated with work engagement $(r=.33, p<.001)$, trust in leadership $(r=.42, p<.001)$, and workaholism $(r=.30, p<.001)$, thus supporting Hypothesis 1 , which states a positive relation to exist between paternalistic leadership and work engagement. Furthermore, we ran a parallel mediation model where paternalistic leadership is the exogenous variable, workaholism and trust in leadership are the mediators, and work engagement is the outcome variable. We found paternalistic leadership to predict both trust in leadership $(\beta=.66, p<.001)$ and workaholism $(\beta=.31, p<.001)$. Both trust in leadership $(\beta=.199, p<.001)$ and workaholism $(\beta=.199, p<.001)$ positively predict work engagement. Furthermore, paternalistic leadership's direct effect on work engagement becomes insignificant when controlling for trust in leadership and workaholism $(\beta=-0.04, p=.558)$.

\section{Table 2}

Results from the Regression Analyses

\begin{tabular}{|c|c|c|c|c|c|c|}
\hline \multirow{2}{*}{$\begin{array}{c}\text { Predictors } \\
\text { Direct Effects }\end{array}$} & \multicolumn{2}{|c|}{$\begin{array}{c}\text { Step } 1 \\
\text { Trust in leader }\end{array}$} & \multicolumn{2}{|c|}{$\begin{array}{c}\text { Step } 2 \\
\text { Workaholism }\end{array}$} & \multicolumn{2}{|c|}{$\begin{array}{c}\text { Step } 3 \\
\text { Work Engagement }\end{array}$} \\
\hline & Estimate & $S E$ & Estimate & $S E$ & Estimate & $S E$ \\
\hline Constant & 1.194 & 0.298 & 2.367 & 0.354 & 1.840 & 0.312 \\
\hline Gender & 0.086 & 0.083 & $0.241^{*}$ & 0.098 & 0.037 & 0.079 \\
\hline Age & 0.003 & 0.004 & $0.013^{* *}$ & 0.005 & 0.003 & 0.004 \\
\hline Education Level & 0.038 & 0.032 & -0.034 & 0.038 & -0.012 & 0.031 \\
\hline $\begin{array}{l}\text { Paternalistic } \\
\text { leadership }\end{array}$ & $0.663^{* * *}$ & 0.046 & $0.305^{* * *}$ & 0.054 & -0.035 & 0.060 \\
\hline Trust in leader & & & & & $0.199^{* * *}$ & 0.060 \\
\hline Workaholism & & & & & $0.449^{* * *}$ & 0.051 \\
\hline \multicolumn{7}{|l|}{ Indirect Effects } \\
\hline \multicolumn{7}{|l|}{ leader } \\
\hline $\begin{array}{l}\text { through } \\
\text { workaholism }\end{array}$ & & & & & $0.137^{* * *}$ & 0.036 \\
\hline$F$ & 54.0 & & 11. & & 22. & \\
\hline$R 2$ & 0.4 & & 0.1 & & 0.3 & \\
\hline
\end{tabular}


Since all relevant relationships are significant in the model, mediation tests are eligible for testing. When investigating the specific indirect effects, we have found paternalistic leadership to have a significant positive indirect effect through trust in leadership (indirect effect $=.132, S E=.060,95 \%$ BC CI $[.024, .223]$ ) and through workaholism (indirect effect $=.137, S E=.051,95 \%$ BC CI $[.068, .206]$ ), indicating full mediation as the direct effect is insignificant. Therefore, Hypotheses 2 and 3 are supported.

\section{Discussion}

We aimed to shed light on why paternalistic leadership is effective in Turkish business culture with this study. As such, we have focused on two possible underlying mechanisms (i.e., workaholism and trust-in-leadership) that employees can experience working with paternalistic leaders, as opposed to leader behaviors.

\section{Implications for Theory and Practice}

Although debate exists in global research about the effectiveness of paternalistic leadership style (Cheng et al., 2014), several studies have shown adopting paternalistic leadership to be beneficial in Turkish organizations (Göncü et al., 2014). However, very few studies have revealed why or how PL produces this effect by examining the mediating processes between paternalist leadership and organizational outcomes (Öge et al., 2018; Bekmezci \& Y1ldız, 2019). In line with these findings, we have found employees to have higher work engagement when they work with a leader who exhibits paternalistic features. In other words, employees work excessively and compulsively when they work with a paternalistic leader; employees also trust their leader in this case, which makes them engage in their work.

Our study contributes to the knowledge in the paternalist leadership literature, showing PL to lead to work engagement through employees' workaholic tendencies and trust in leadership. Our first contribution is the confirmation of PL's positive effect on employee motivation and well-being (i.e., work engagement) in the context of work in Turkey (Öge et al., 2018; Bekmezci \& Yıldız, 2019).

Our second contribution is the explanation of why and how PL strategy is beneficial by employing two different underlying mechanisms: relational (i.e., trust in leadership) and task-related (i.e., workaholism). These findings are in line with self-determination theory (Deci \& Ryan, 2000), with needs satisfaction in terms 
of relatedness and mastery leading to well-being. Although these two may seem contradictory, this finding may partly be due to two paternalistic leadership facets (e.g., authority and benevolence). Our finding on PL's effect on workaholism is consistent with previous studies that have shown paternalistic leaders to be demanding (Chan, Huang, Snape, \& Lam, 2013), make employees perform work tasks with extra care, and show personal devotion to their job (Ersoy, Born, Derous, \& van der Molen, 2012). Paternalistic managers may ask their employees to remain involved with their work even after work hours and put in extra effort when needed. The positive effect of paternalistic leadership on trust in leadership also confirms the results reported in previous studies in other countries (Wu \& Xu, 2012; Saher et al., 2013; Chen et al., 2014; Hiller et al., 2019) as well as in Turkey (Ç1raklar et al., 2016; Apaydın, 2017). One can claim PL's aspects of authority and benevolence to jointly generate a safe zone for Turkish employees due to obeying the leader as well as being cared for by the leader.

In terms of practical implications, our study shows that adopting a leadership style that reflects behaviors such as caring for employees both in and out of work, giving advice for all domains of life, and expressing performance expectancy and loyalty can be useful in the context of Turkish business. Therefore, we suggest that managers should adopt traits like showing individual consideration and task management if they want their subordinates to engage in work. Getting involved in subordinates' non-work-related life problems, asking about their families, demonstrating interest in their well-being, and explicitly pushing them to exert more effort are effective strategies. Our study shows that managers in the context of Turkish culture should also take care of their employees during non-business hours, such as by asking them anything about their private life or dancing at their wedding. These actions may create a loyal feeling among employees toward their manager.

\section{Limitations and Suggestions}

Despite its significant contributions, this study has several limitations. First, the primary limitation is the cross-sectional study design. The possibility of participants' moods changing based on recent events is a well-known phenomenon while responding to scales. Second, all data in the survey have been collected using the self-report method. This method is known to be able to cause common method bias. Future studies are recommended to utilize the multi-sourcing method for evaluating the perception of respondents in terms of the study variables. Therefore, 
employees and managers may be included in future studies by collecting data from multiple reports. In addition, participants may have been affected by social desirability response bias while answering the scale's items. Third, we measured nothing for needs satisfaction in terms of autonomy in this perspective study. Subsequent studies should not ignore this concept's role in the relationship. We also measured paternalistic leadership using a short scale with a single factor construct rather than through dimensions. Future research should use a longer scale with multiple constructs and all the dimensions of PL.

At the same time, future studies can use the longitudinal design as a diary or two or three wave panel design. Furthermore, different data sources may be included in future studies such as paternalist leadership rated by employees and work engagement rated by the leader of each subordinate. In particular, participation in decision making and job crafting may be indicative of needs satisfaction in terms of autonomy. Finally, future studies' ability to employ moderating variables such as job satisfaction, psychological capital, or self-efficacy should not be ignored in order to show under which conditions these links are significant.

\section{References | Kaynakça}

Andreassen, C. S., Griffiths, M. D., Sinha, R., Hetland, J., \& Pallesen, S. (2016). The relationships between workaholism and symptoms of psychiatric disorders: A large-scale cross-sectional study. PLoS One, 11(5), e0152978.

Apaydın, E. (2017). Paternalistik liderliğin değişime direnç üzerine etkileri: Örgütsel güvenin aracılık rolü. (Unpublished Master Thesis). Bahçeşehir University Institute of Social Sciences.

Aycan, Z. (2008). Cross-cultural approaches to leadership. Handbook of Crosscultural Management Research (pp. 219-238).

Aycan, Z. (2015). Paternalistic leadership. In Wiley Encyclopedia of Management (pp. 1-2).

Aycan, Z., Schyns, B., Sun, J. M., Felfe, J., \& Saher, N. (2013). Convergence and divergence of paternalistic leadership: A cross-cultural investigation of prototypes. Journal of International Business Studies, 44(9), 962-969.

Bakker, A. B., Demerouti, E., \& Schaufeli, W. B. (2002). Validation of the Maslach Burnout Inventory- General Survey: An Internet study. Anxiety, Stress \& Coping, 15, 245-260.

Bekmezci, M., \& Yıldız, B. (2019). Babacan liderlik psikolojik sahipliği nasıl etkilemektedir? Kolektif şükranın aracı rolü, İstanbul Ticaret Üniversitesi Sosyal Bilimler Dergisi, 18(35), 309-324.

Bing, S. (2004). Sun Tzu was a sissy: Conquer your enemies, promote your friends, and wage the real art of war. Harper Collins.

Bowen, N. K., \& Guo, S. (2011). Structural equation modeling. Oxford University Press.

Börü, D., İslamoğlu, G., \& Birsel, M. (2007). Güven: Bir anket geliştirme çalışması. Öneri Dergisi, 27(7), 49-59. 
Brower H. H., Lester, S. W., Korsgaard, M. A., \& Dineen, B. R. (2009). A closer look at trust between managers and subordinates: understanding the effects of both trusting and being trusted on subordinate outcomes. Journal of Management, 35(2), 327-347.

Burke, C. S., Sims, D. E., Lazzara, E. H., \& Salas, E. (2007). Trust in leadership: A multi-level review and integration. The Leadership Quarterly, 18(6), 606-632.

Chan, S. C., Huang, X., Snape, E., \& Lam, C. K. (2013). The Janus face of paternalistic leaders: Authoritarianism, benevolence, subordinates' organization-based self-esteem, and performance. Journal of Organizational Behavior, 34(1), 108-128.

Chen, X. P., Eberly, M. B., Chiang, T. J., Farh, J. L., \& Cheng, B. S. (2014). Affective trust in Chinese leaders: Linking paternalistic leadership to employee performance. Journal of Management, 40(3), 796-819.

Cheng, J. W., Chang, S. C., Kuo, J. H., \& Cheung, Y. H. (2014). Ethical leadership, work engagement, and voice behavior. Industrial Management \& Data Systems, 114(5), 817-831.

Choi, S. B., Tran, T. B. H., \& Park, B. I. (2015). Inclusive leadership and work engagement: Mediating roles of affective organizational commitment and creativity. Social Behavior and Personality: An International Journal, 43(6), 931-943.

Christian, M. S., Garza, A. S., \& Slaughter, J. E. (2011). Work engagement: A quantitative review and test of its relations with task and contextual performance. Personnel Psychology, 64, 89-136.

Chughtai, A., Byrne, M., \& Flood, B. (2015). Linking ethical leadership to employee well-being: The role of trust in supervisor. Journal of Business Ethics, 128(3), 653-663.

Clark, M. A., Smith, R. W., \& Haynes, N. J. (2020). The Multidimensional Workaholism Scale: Linking the conceptualization and measurement of workaholism. Journal of Applied Psychology. Advance online publication. https://doi.org/10.1037/apl0000484

Cummings, L. L., \& Bromiley, P. (1996). The organizational trust inventory (OTI). Trust in Organizations: Frontiers of Theory and Research, 302(330), 39-52.

Cenkci, A. T., \& Özçelik, G. (2015). Leadership styles and subordinate work engagement: The moderating impact of leader gender. Global Business \& Management Research, 7(4), 8-20.

Çetin, C., Toylan Vatansever, N., Çakırel Aydıner, Ö., \& Çakırel, Y. (2017). Paternalistic leadership and psychological well-being: The mediating role of meaningful work. Fatih Sultan Mehmet İlmi Araştırmalar İnsan ve Toplum Bilimleri Dergisi, 10, 81-113.

Çıraklar, N. H., Ucar, Z., Sezgin, O. B. (2016). Effects of paternalistic leadership on organizational identification: Mediating role of trust in leader. Research Journal Business. Management, 3(1), 73-87.

Çıtır, I. Ö., \& Kavi, E. (2010). Algılanan örgütsel güven ile iş güvencesi arasındaki ilişkiye yönelik bir araştırma. Yönetim Bilimleri Dergisi, 8(2), 229-243.

De Clercq, D., Bouckenooghe, D., Raja, U., \& Matsyborska, G. (2014). Servant leadership and work engagement: The contingency effects of leader-follower social capital. Human Resource Development Quarterly, 25(2), $183-212$.

Del Líbano, M., Salanova, M., \& Schaufeli, W. (2010). Validity of a brief workaholism scale. Psicothema-Revista de Psicologia, 22(1), 143-150.

Diffie-Couch, P. (1984). Building a feeling of trust in the company. Supervisory Management, 29(4), 31-36.

Dirks, K. T., \& Ferrin, D. L. (2002). Trust in leadership: Meta-analytic findings and implications for research and practice. Journal of Applied Psychology, 87(4), 611. 


\section{insan \& toplum}

Engelbrecht, A. S., Heine, G., \& Mahembe, B. (2017). Integrity, ethical leadership, trust and work engagement. Leadership \& Organization Development Journal, 38(3), 368-379.

Erben, G. S., \& Güneşer, A. B. (2008). The relationship between paternalistic leadership and organizational commitment: Investigating the role of climate regarding ethics. Journal of Business Ethics, 82(4), 955-968.

Ersoy, N. C., Born, M. P., Derous, E., \& van der Molen, H. T. (2012). The effect of cultural orientation and leadership style on self-versus other-oriented organizational citizenship behaviour in Turkey and the Netherlands. Asian Journal of Social Psychology, 15(4), 249-260.

Farh, J. L., \& Cheng, B. S. (2000). A cultural analysis of paternalistic leadership in Chinese organizations. In Management and organizations in the Chinese context (pp. 84-127). Palgrave MacMillan.

Gawke, J. C., Gorgievski, M. J., \& Bakker, A. B. (2017). Employee intrapreneurship and work engagement: A latent change score approach. Journal of Vocational Behavior, 100, 88-100.

Giallonardo, L. M., Wong, C. A., \& Iwasiw, C. L. (2010). Authentic leadership of preceptors: Predictor of new graduate nurses' work engagement and job satisfaction. Journal of Nursing Management, 18(8), 993-1003.

Göncü, A., Aycan, Z., \& Johnson, R. E. (2014). Effects of paternalistic and transformational leadership on follower outcomes. The International Journal of Management and Business, 5(1), 36-58.

Hayes, A. F. (2009). Beyond Baron and Kenny: Statistical mediation analysis in the new millennium. Communication Monographs, 76(4), 408-420.

Hayes, A. F. (2017). Introduction to mediation, moderation, and conditional process analysis: A regression-based approach. Guilford Publications.

Hayes, A. F., Montoya, A. K., \& Rockwood, N. J. (2017). The analysis of mechanisms and their contingencies: PROCESS versus structural equation modeling. Australasian Marketing Journal, 25(1), 76-81.

Hayes, A. F., \& Rockwood, N. J. (2017). Regression-based statistical mediation and moderation analysis in clinical research: Observations, recommendations, and implementation. Behaviour Research and Therapy, 98, 39-57.

He, G., An, R., \& Hewlin, P. F. (2019). Paternalistic leadership and employee well-being: A moderated mediation model. Chinese Management Studies, 13(5). doi: 10.1108/CMS-10-2018-0724

Hiller, N. J., Sin, H. P., Ponnapalli, A. R., \& Ozgen, S. (2019). Benevolence and authority as weirdly unfamiliar: A multi-language meta-analysis of paternalistic leadership behaviors from 152 studies. The Leadership Quarterly, 30(1), 165-184.

Hofstede, G. (1980). Culture's consequences: International differences in work-related values. Sage Publications.

Hofstede, G. (2001). Culture's consequences: Comparing values, behaviors, institutions and organizations across nations (2nd ed.). Sage Publications.

Holland, P., Cooper, B., \& Sheehan, C. (2017). Employee voice, supervisor support, and engagement: The mediating role of trust. Human Resource Management, 56(6), 915-929.

Hu, L. T., \& Bentler, P. M. (1999). Cutoff criteria for fit indexes in covariance structure analysis: Conventional criteria versus new alternatives. Structural Equation Modeling: A Multidisciplinary Journal, 6(1), 1-55.

İslamoğlu, G., Birsel, M., \& Börü, D. (2007). Trust in organization. İnkılap Kitabevi.

Jaiswal, N. K., \& Dhar, R. L. (2017). The influence of servant leadership, trust in leader and thriving on employee creativity. Leadership \& Organization Development Journal, 38(1), 2-21.

Korkmaz, F., Gökdeniz, İ., \& Zorlu, K. (2018). Paternalist liderlik davranışının örgütsel özdeşleşme üzerindeki etkisinde çalışanların işe tutkunluk düzeylerinin aracılık rolü. İşletme Araştırmaları Dergisi, 10(3), 950-973. 
Kurt, İ., \& Yahyagil, M. Y. (2015). Universal values, creative behavior and leadership: Turkish case. International Business Research, 8(6), 89.

Liao, S. H., Widowati, R., Hu, D. C., \& Tasman, L. (2017). The mediating effect of psychological contract in the relationships between paternalistic leadership and turnover intention for foreign workers in Taiwan. Asia Pacific Management Review, 22(2), 80-87.

Liden, R. C., Wayne, S. J., \& Sparrowe, R. T. (2000). An examination of the mediating role of psychological empowerment on the relations between the job, interpersonal relationships, and work outcomes, Journal of Applied Psychology, 85(3), 407-416.

Maccoby, M. 2004. The power of transference. Harvard Business Review, 82(9), 76-85.

Mayer, R. C., Davis, J. H., \& Schoorman, F. D. (1995). An integrative model of organizational trust. Academy of Management Review, 20(3), 709-734.

Mete, Y. A., \& Serin, H. (2015). Relationship between school administrators' paternalist leadership behaviours and teachers' organizational citizenship and organizational cynicism behaviours. The Journal of Hasan Ali Yücel Education Faculty, 12, 147-159.

Mo, S., \& Shi, J. (2017). Linking ethical leadership to employee burnout, workplace deviance and performance: Testing the mediating roles of trust in leader and surface acting. Journal of Business Ethics, 144(2), 293-303.

Nal, Ü. M., \& Tarım, M. (2019). Paternalist liderliğin örgütsel adalet algısı üzerine etkisi: Sağlık çalışanları üzerinde bir araştırma. Afyon Kocatepe University Journal of Social Sciences, 21(4).

Oates, W. E. (1971). Confessions of a workaholic: The facts about work addiction. World Publishing Company.

Öge, E., Cetin, M., \& Top, S. (2018). The effects of paternalistic leadership on workplace loneliness, work family conflict and work engagement among air traffic controllers in Turkey. Journal of air transport management, 66, 25-35.

Patrick, H., Knee, C. R., Canevello, A., \& Lonsbary, C. (2007). The role of need fulfillment in relationship functioning and well-being: A self-determination theory perspective. Journal of Personality and Social Psychology, 92(3), 434.

Pellegrini, E. K., \& Scandura, T. A. (2008). Paternalistic leadership: A review and agenda for future research. Journal of Management, 34(3), 566-593.

Podsakoff, P. M., MacKenzie, S. B., Moorman, R. H., \& Fetter, R. (1990). Transformational leader behaviors and their effects on followers' trust in leader, satisfaction, and organizational citizenship behaviors. The Leadership Quarterly, 1(2), 107-142.

Preacher, K. J., \& Hayes, A. F. (2004). SPSS and SAS procedures for estimating indirect effects in simple mediation models. Behavior Research Methods, Instruments, \& Computers, 36(4), 717-731.

Rawat, P. S., \& Lyndon, S. (2016). Effect of paternalistic leadership style on subordinate's trust: An Indian study. Journal of Indian Business Research, 8(4), 264-277.

Rousseau, D., Sitkin, S., Burt, R., \& Camerer, C. (1998). Not so different after all: A cross discipline view of trust. Academy of Management Review, 23, 405-421.

Ryan, R. M., \& Deci, E. L. (2000). Self-determination theory and the facilitation of intrinsic motivation, social development, and well-being. American Psychologist, 55(1), 68.

Saher, N., Naz, S., Tasleem, I., Naz, R., \& Kausar, S. (2013). Does paternalistic leadership lead to commitment? Trust in leader as moderator in Pakistani context. Interdisciplinary Journal of Contemporary Research in Business, 5(1), 443-455. 


\section{insan \& toplum}

Schaufeli, W. B., Bakker, A. B., \& Salanova, M. (2006). The measurement of work engagement with a short questionnaire: A cross-national study. Educational and Psychological Measurement, 66(4), 701-716.

Schaufeli, W. B., Salanova, M., Gonzalez-Romá, V., \& Bakker, A. B. (2002). The measurement of engagement and burnout: A confirmative analytic approach. Journal of Happiness Studies, 3, 71-92.

Schaufeli, W. B., Taris, T. W., \& Bakker, A. B. (2006). Dr. Jekyll or Mr. Hyde: On the differences between work engagement and workaholism. In Research Companion to Working Time and WorkAddiction (pp. 193-217).

Schoorman, F. D., Mayer, R. C., \& Davis, J. H. (2007). An integrative model of organizational trust: Past, present, and future. The Academy of Management Review, 32(2), 344-354. https://doi.org/10.2307/20159304

Shu, C. Y. (2015). The impact of intrinsic motivation on the effectiveness of leadership style towards on work engagement. Contemporary Management Research, 11(4), 327-350.

Si, W., Farh, J. L., Qu, Q., Fu, P. P., \& Kang, F. (2017). Paternalistic leadership in China: A latent profile analysis of its antecedents and outcomes. In Academy of Management Proceedings, 1, 15057. Academy of Management.

Six, F. E. (2007). Building interpersonal trust within organizations: a relational signaling perspective. Journal of Management \& Governance, 11(3), 285-309.

Soylu, S. (2011). Creating a family or loyalty-based framework: The effects of paternalistic leadership on workplace bullying. Journal of Business Ethics, 99(2), 217-231.

Suer, F. C. (2017). The effect of leadership styles on employees' psychological empowerment and the gender role in this relation. Research Journal of Business and Management, 4(4), 434-446.

Taris, T. W., Schaufeli, W. B., \& Shimazu, A. (2010). The push and pull of work: The differences between workaholism and work engagement. In Work engagement: A Handbook of Essential theory and Research (pp. 39-53).

Tims, M., Bakker, A. B., \& Xanthopoulou, D. (2011). Do transformational leaders enhance their followers' daily work engagement? The Leadership Quarterly, 22(1), 121-131.

Wasti, S., Tan, H. H., Brower, H. H. \& Önder, Ç. (2007). Cross-cultural measurement of supervisor trustworthiness: an assessment of measurement invariance across three cultures. Leadership Quarterly, 18(5), 477-489.

Wu, M., Huang, X., \& Chan, S. C. H. (2012) The influencing mechanisms of paternalistic leadership in mainland China, Asia Pacific Business Review, 18(4), 631-648. doi 10.1080/13602381.2012.690940

Wu, M., Huang, X., Li, C., \& Liu, W. (2012). Perceived interactional justice and trust-in-supervisor as mediators for paternalistic leadership. Management and Organization Review, 8(1), 97-121.

Wu, M., \& Xu, E. (2012). Paternalistic leadership: from here to where?. In Handbook of Chinese Organizational Behavior. Edward Elgar Publishing.

Xanthopoulou, D., Bakker, A. B., Demerouti, E., \& Schaufeli, W. B. (2009). Reciprocal relationship between job resources, personal resources and work engagement. Journal of Vocational Behavior, 74(3), 235-244.

Xanthopoulou, D., Bakker, A. B., Heuven, E., Demerouti, E., \& Schaufeli, W. B. (2008). Working in the sky: A diary study on work engagement among flight attendants. Journal of Occupational Health Psychology, 13(4), 345-356. doi:10.1037/1076-8998.13.4.345. 